\title{
Washington Steel Corp. v. TW Corp.: Bank Confidentiality in Corporate Takeovers
}

The role of commercial banks in financing hostile tender offers has recently been subject to increasing public scrutiny. ${ }^{1}$ Since larger commercial banks typically have an extensive network of corporate clients, it is predictable that the target corporation of a hostile tender offer will occasionally be a client of the bank financing the takeover attempt. A troubling question has arisen in this context as to wlrether the financing bank owes any duty of loyalty to the target, particularly when the target has entrusted the bank with confidential financial information in the course of their prior relationship. To date, the few cases that have dealt with the issue seem to have imposed a limited duty on the bank not to rely upon confidential information entrusted by the target in making its decision to finance the takeover. ${ }^{2}$

In Washington Steel Corp. v. TW Corp. ${ }^{3}$ however, the Court of Appeals for the Third Circuit recently suggested in dicta that commercial banks may use confidential information for internal purposes in the takeover context. This Note will argue that the Washington Steel decision goes too far in limiting the duties of a bank by failing to require the protection of confidential information from potential misuse. A bank need not be precluded from financing takeovers of its clients; however, imternal banking procedures should be implemented to insu-

1. See generally Herzel \& Rosenberg, Loans to Finance Tender Offers: The Bank's Legal Problems, 96 BANkING L.J. 676 (1979); Note, Bank Financing of Involuntary Takeovers of Corporate Customers: A Breach of a Fiduciary Duty?, 53 Notre DAME LAw. 827 (1978); Cole, Role of Banks Challenged in Unfriendly Takeovers, N.Y. Times, June 11, 1979, at D1, col. 1; Shapiro, Bankers in a Bind, INSTITUTIONAL INVESTOR, June 1979, at 59.

The increasingly prominent role played by commercial banks in takeovers is due in part to an increase in cash tender offers. With a depressed equities market, the acquiring companies have preferred to offer cash, rather than their undervalued stock, in exchange for the shares of the target corporation. The acquiring companies thus naturally turn to comınercial banks as the most convenient source of funds to finance such transactions. See Schwartz \& Kelly, Bank Financing of Corporate Acquisitions-The Cash Tender Offer, 88 BANKIng L.J. 99 (1971).

However, the current period of credit tightness may well signal a downturn in takeovers, and, thus, less bank activity in the area. See Lancaster \& Leff, Fed's Move on Money Is Expected to Cool Off Hot Takeover Market, Wall St. J., Oct. 15, 1979, at 1, col. 6.

2. See Humana, Inc. v. American Medicorp, Inc., [1977-1978 Transfer Binder] FED. SEc. L. REP. (CCH) || 96,286 (S.D.N.Y. Jan. 5, 1978); American Medicorp, Inc. v. Continental Ill. Nat'1 Bank, No. 77 C 3865 (N.D. Ill. Dec. 30, 1977) (unpublishcd opinion); Harnischfeger Corp. v. Paccar Inc., [1979] 2 Trade Cas. (CCH) I 62,786 (E.D. Wis. July 10, 1979). See also Registration of Tender Offer by Brascan U.S.A., Inc. for the Cominon Stock of F.W. Woolworth Co., S. Carolina Sec. Counm'r (May 14, 1979) (unpublished administrative opinion).

3. 602 F.2d 594 (3d Cir. 1979). 
late information received in confidence. This Note will also propose an analysis of the critieal but largely ignored causation and harm issues encountered in this context.

Part I discusses the common law approaches to the confidentiality issue prior to and including the Washington Steel decision. Part II analyzes the Washington Steel court's reasoning on the breacli of confidentiality issue. In addition, it examnines alternative procedural inechanisms for the protection of confidential information, and assesses additional relevant issues inadequately explored by the Washington Steel court. This Note concludes that the central concern in future judieial considerations of this problem should be the protection of the reasonable expectations of the parties involved.

\section{I \\ Case Law \\ A. Common Law Approaches to Bank Confidentiality}

Two distinct theories may be employed under the common law to protect bank-client confidentiahty. Courts have typically resorted to either an implied contract or a fiduciary theory in examining the confidentiality issue.

\section{Implied Contract}

The common law has traditionally employed an implied contract theory to protect the confidentiality of bank clients. This thcory givcs legal form to the reasonable expectations of the parties by implying a promise on the part of the bank not to disclose information about the client's accounts or financial affairs to third parties. ${ }^{4}$

The seminal case employing the implied contract analysis is Tournier v. National Provincial and Union Bank of England, ${ }^{5}$ an Enghish case relied on in numerous American jurisdictions. In Tournier, plaintiff owed payinents to the defendant bank. Another bank customer wrote plaintiff a check whicls he endorsed over to a third person. When the check returned to the defendant bank, the bank manager asked the third person's bank for the identity of this third person. He was informed that the third person was a bookmaker. The manager later disclosed this fact to the plaintiff's employer, prompting him to fire the plaintiff. The court held that the bank had an imphicd contractual duty

4. Milohnich v. First Nat'l Bank, 224 So. $2 d 759$ (Fla. Dist. Ct. App. 1969); Peterson v. Idaho First Nat'l Bank, 83 Idaho 578, 367 P.2d 284 (1961); Graney Dev. Corp. v. Taksen, 92 Misc. 2d 764, 400 N.Y.S.2d 717 (Sup. Ct. 1978); Annot., 92 A.L.R.2d 900 (1963). See also United States v. First Nat'l Bank, 67 F. Supp. 616 (S.D. Ala. 1946).

5. [1924] 1 K.B. 461. 
of confidence not to disclose customer information to third parties, and that the bank was hable for the consequences of its breach.

In Peterson v. Idaho First National Bank, ${ }^{6}$ the leading American case, a bank was similarly held liable to a depositor for disclosmg to his employer that many of his checks were being returned for lack of sufficient funds. The court stated:

It is implicit in the contract of the bank with its customer or depositor that no information nay be disclosed by the bank or its employees concerning the custoiner's or depositor's account, and that, unless authorized by law or by the custoiner or depositor, the bank inust be held liable for breach of the implied contract. ${ }^{7}$

While thcse cases inay be factually distinguishable from the takeover context in that both imvolved disclosure of confidential information to third parties rather than internal misuse, the same crucial consideration in both cases is relevant to this imquiry. A commercial bank is granted access to confidential information by a client with the understanding that the bank nay not use such information in a manner that does not further the purposes underlying the contract. Moreover, it is certainly not intended that the bank use the information to the detriment of that client.

In the corporate takeover context, the implied contract theory would suggest that a bank should be precluded froin considering confidential information im its takeover financing decision. This reasoning, however, has not been employed in the recent takeover cases mvolving bank customer confidential information.

\section{The Fiduciary Theory}

Another line of cases suggests that in certain circuinstances the bank-client relationship can be viewed as fiduciary or confidential in nature. Although normally the relationship between a bank and a borrower is merely that of creditor-debtor, ${ }^{8}$ the courts have found that when a bank has accepted a chent's trust and confidence, the bank can be held to a fiduciary standard of conduct. ${ }^{9}$

Pigg v. Robertson, ${ }^{10}$ a recent Missouri Court of Appeals case, is an

6. 83 Idaho 578,367 P.2d 284 (1961).

7. Id. at 588,367 P.2d at 290 .

8. Stewart v. Phoenix Nat'l Bank, 49 Ariz. 34, 64 P.2d 101 (1937).

9. Brasher v. First Nat'l Bank, 232 Ala. 340, 168 So. 42 (1936); Stewart v. Phoenix Nat'1 Bank, 49 Ariz. 34, 64 P.2d 101 (1937); Rutherford v. Rideout Bank, 11 Cal. 2d 479, 80 P.2d 978 (1938); First Nat'l Bank v. Brown, 181 N.W.2d 178 (lowa 1970); Pigg v. Robertson, 549 S.W.2d 597 (Mo. Ct. App. 1977); Annot., 70 A.L.R.3d 1344 (1976). For cases recognizing the rule but distinguished on factual grounds, see Manson State Bank v. Tripp, 248 N.W.2d 105 (lowa 1976); Klein v. First Edina Nat'l Bank, 293 Minn. 418, 196 N.W.2d 619 (1972); First Am. Nat'l Bank v. Mitchell, 359 So. 2d 1376 (Miss. 1978).

10. 549 S.W.2d 597 (Mo. Ct. App. 1977). 
example of this fiduciary approacl as applied to the situation in which a bank has been entrusted with confidential information. Plaintiff, conteinplating purcliase of a particular farm, sought a loan from a bank of which he was a longstanding customer. Plamtiff was directed to see defendant Robertson, who was seated at the bank president's desk. Plamtiff explained his purchase opportunity to Robertson, who refused to make the loan. Within hours Robertson arranged to purchase this same farm for himself, selling it seven months later for a substantial profit. It was subsequently discovered that Robertson, unbeknownst to the plaintiff, was not in fact a bank officer, but rather was an auditor retained by the bank for specific auditing services. Plamtiff sued Robertson for violation of an alleged confidential relationship.

The court's decision followed a fiduciary analysis of the bank-custoiner relationship. It found that when a bank officer accepts imformation froin a custoiner in confidence, the officer may not use the information for his own profit, to the harm of the customer. The fact that Robertson was not a bank employee did not affect the result, because Robertson had placed himself in a position in which bank custoiners naturally assumed he was a bank officer. The customers therefore had a right to expect the same confidentiahty from him as from a regular bank officer. The court therefore found sufficient evidence to reverse the trial court's directed verdict for Robertson.

The first judicial assessinent of a bank duty of confidentiality to its clients in a corporate takeover context applied a fiduciary approach to the confidentialty issue. In American Medicorp, Inc. v. Continental Illinois National Bank, ${ }^{11}$ plamtiff sued its bank, Continental Illinois, for participating in the financing of a hostile takeover bid initiated by Humana, Inc. Plaintiff clainied to have given the bank specific "nonpublic" financial and related commercial information which precluded Continental Illinois' participation in the challenged takeover financing. Plaintiff charged that the bank's participation constituted a per se violation of its fiduciary obligations or, in the alternative, that the bank breaclied its obligation by actually using the confidential information in deciding to finance the takeover attempt.

The District Court for the Nortlern District of Illinois rejected this per se rule on the basis of insufficient precedent. It went on to imply, however, that a bank liad a duty not to inisuse a client's confidential information:

[A] bank is not precluded under all circumstances from making a loan to facilitate the attempted takeover of a customer. If it does not rely on the confidential information of its customers in its files, we believe that

11. American Medicorp, Inc. v. Continental Ill. Nat'l Bank, No. 77 C 3865 (N.D. 11l. Dec. 30 , 1977) (unpublished opinion). For a commentary on this case, see Note, supra note 1. 
a bank is free to deal with any customer who comes to it. ${ }^{12}$

The court found that although some of the bank officers involved in the Humana loan had read portions of the American Medicorp credit file, there was no showing that they had used the nnaterial in deciding ultimately to make that loan. ${ }^{13}$ The evidence indicated that the bank officers evaluated the loan in rehiance on Humana's rather than American Medicorp's financial condition. It therefore did not support plaintiff's claim of a misuse of confidential information.

Curiously, the court in American Medicorp never explicitly asserted the existence of a duty. It went to great lengths, however, to demonstrate that the evidence did not indicate a "violation of trust."14 In the absence of a duty, this is an irrelevant issue. The better readimg of the case, therefore, is that the court impliedly found a bank duty not to misuse confidential information entrusted to it.

Moreover, in the companion case of Humana, Inc. v. American Medicorp, Inc. ${ }^{15}$ the District Court for the Southern District of New York unequivocally found such a bank duty on similar facts by einploying a fiduciary analysis: "[A] special relationship which may be designated fiduciary or confidential, does exist between a prospective borrower and its bank which should preclude the bank from disseminating or using the information for improper purposes."16 But, as in American Medicorp, the court found no evidence of misuse of confidential information. ${ }^{17}$

In sum, the cases have uniformly recognized that a bank has a duty not to use confidential information to the harm of its clients. The recent takeover decisions have described this duty as fiduciary. Regardless of its characterization, this duty is grounded on the reasonable expectations of the parties. The Washington Steel decision unfortunately represented an abrupt departure from these well-established primciples.

12. American Medicorp, Inc. v. Continental Ill. Nat'l Bank, No. 77 C 3865 at 7.

13. Id. at 11 .

14. Id.

15. [1977-1978 Transfer Binder] FED. SEC. L. REP. (CCH) II 96,286 (S.D.N.Y. Jan. 5, 1978).

16. Id. at 92,829 .

17. In Humana, unlike in American Medicorp, the court was not presented with evidence that bank officers working on the loan were familiar with the confidential information entrusted by American Medicorp. Id.

In Harnischfeger Corp. v. Paccar Inc., [1979] 2 Trade Cas. (CCH) If 62,786 (E.D. Wis. July 10, 1979), the only other judicial decision addressing this issue, the District Court for the Eastern District of Wisconsin also found no evidence of a breach of fiduciary duty, but did not clearly articulate whether such a duty existed. 


\section{B. The Washington Steel Decision}

In January 1979, Talley Industries ${ }^{18}$ attempted a cash takeover of Washington Steel with partial financing from Chemical Bank. Washington Steel had previously given the bank nonpublic financial information which included sensitive cash flow and earnings projections througl 1983. After Talley had arranged this financing it proposed a cash merger, whicl Washington Steel's management urged its stockholders to reject. Washington Steel then sued both Talley and Cheinical Bank to enjom the transaction, alleging, in part, ${ }^{19}$ that the bank had breached its common law fiduciary duty to Washington Steel by misusing confidential information entrusted to it $\mathrm{m}$ deciding to finance the tender offer.

The District Court for the Western District of Pennsylvania ruled in favor of Washington Steel and granted a preliminary injunction solely on the basis of the breach of fiduciary duty count. ${ }^{20}$ The court found that the bank was Washington Steel's "agent" and "was purporting to advance the several corporate purposes of Plaintiff Washington Steel at all relevant times . . . ."21 This agency created fiduciary duties that the bank breacled when it aided the takeover bid against Washington Steel and concealed its adverse agency relationship. The court apparently did not even reacl the question of whether there had been any misuse of confidential information.

On appeal, respondent Washington Steel proposed two alternative theories of liability. First, it urged a per se rule in arguing that a bank, by receiving confidential information from a bank client, assumes a fiduciary duty not to act on behalf of a competing company whose objective is to subvert the bank client's capital development program. Chemical Bank violated this duty by financing Talley's takeover bid. Second, Washington Steel offered to introduce evidence that Chemical Bank had violated its duty not to misuse confidential imformation entrusted to it. Cliemical Bank violated this duty by considermg such information in evaluating the merits of the loan to Talley.

The court mitially rejected the proposed per se rule as an unprecedented approach under the common law. The primcipal rationales for the court's ruling, however, appeared to be first, economic, and second, prophylactic. The court contended that a per se rule could

18. TW Corporation was the subsidiary with which Talley, the parent, intended to merge Washington Steel in order to effectuate the takeover.

19. Washington Steel also contended that Talley's acts had violated $\S \S 14(\mathrm{~d})$ and (e) of the Securities Exchange Act of 1934, 15 U.S.C. $\$ \$ 78$ n(d), (e) (1976).

20. Washington Steel Corp. v. TW Corp., 465 F. Supp. 1100 (W.D. Pa. 1979).

21. Id. at 1103 . 
"wreak havoc with the availability of funding for capital ventures."22 A corporation could try to resist takeover atteinpts, it was argued, by securing loans from a wide range of major commercial banks. By providing confidential information to these banks during the loan application process, the corporation could exploit a per se fiduciary duty rule to preclude bank participation in subsequent takeover financing agreements targeted at it. ${ }^{23}$

The court next turned to the misuse of confidential information claim. It found that Chemical Bank had implemented imstitutional procedures to protect confidential information from misuse, and that there was no evidence that the bank had considered information entrusted to it by Washington Steel in its approval of the takeover financing loan. ${ }^{24}$ The court then mamtained, in dicta, that even if such use had occurred, the bank would not have violated any duty to Washington Steel. ${ }^{25}$ Such a duty "might force banks to go blindly into loan transactions, arguably violating [their] duties to [their] own depositors." 26 In addition, this duty might burden takeover financing by discouraging bank involvement in takeover attempts targeted at its customers.

On these grounds, the court reversed the preliminary injunction. ${ }^{27}$

II

\section{ANALYSIS}

In light of the precedent on the subject, Washington Steel's finding of no duty of bank confidentiality was clearly incorrect. After arguing in support of a bank duty not to misuse client confidential information, this section will propose that certain internal bank procedures are the best available means to protect bank clients. In addition, it will ex-

22. 602 F.2d at 601 .

23. The court also claimed that any state common law rule in this area "would likely give way to the preemptive force of federal law." Id. It cited several federal regulations concerning conflicts of interest between commercial bank loan departments and trust departments which are not particularly relevant to the issue. Although the validity of this argument is questionable, it is not central to the court's holding and will not be discussed here.

24. Nor did the court find that Chemical Bank had disclosed the information to third parties, and thus it expressly declined to pass on the question of a bank's liabilities under $\S 10(b)$ of the Securities Exchange Act of 1934, 15 U.S.C. $\$ 78$ j (1976), and SEC rule 10b-5, 17 C.F.R. 240.10b-5 (1979), promulgated thereunder. 602 F.2d at 603-04.

25. The court stated: "We do not believe that a bank violates any duty it nnay owe to one of its borrowers when it uses information received from that borrower in deciding whether or not to make a loan to another prospective borrower." 602 F.2d at 603.

26. $I d$.

27. Since the ouly issue on appeal was whether a common law fiduciary duty existed, the court did not pass on the question of whether Chemical Bank's conduct violated the Williams Act. Id. at $597 \mathrm{n} .1$. 
amine the causation and harm issues which are both critical elements of a valid cause of action in Washington Steel-type suits.

\section{A. Confidentiality}

\section{The Duty of Confidentiality}

The court's rejection of a bank duty not to use confidential information to the detriment of its client merits initial consideration. The court unconvincingly argued that two dangers were likely to arise from the existence of such a duty. First, it argued that banks would have to grant loans blindly and thereby they would violate their duties to depositors. Second, it contended that such a duty would discourage banks from financing takeovers agamst their own chents.

The appropriate response to the former argument is that a bank that respects the confidentiality of the target's files im making a takeover decision is no inore "blind" than any other bank that is without the benefit of confidential information. Banks regularly agree to finance takeovers of targets to whose confidential files they are not privy. Moreover, a bank's duty toward its depositors is generally that of a debtor to its creditors; ${ }^{28}$ as such, it merely has a duty to repay its debts. It is difficult to see how this duty can be interpreted to preclude a duty of confidentiality on the part of the bank.

It is also unclear why a duty not to inisuse confidential information would create a reluctance among banks to finance takeovers against their clients. Such a duty would merely preclude banks that had inisused confidential information froin financing such a takeover. Where the bank observed its fiduciary obligations and protected confidential information, it would be free to finance a takeover of its chent.

The most disquieting aspect of the Washington Steel court's findmg of no duty, however, was that the court failed to address the underlying issues in this context. Bank and customer entertain certam expectations about permissible bank use of confidential information transinitted to the bank during a loan application process. Central to these expectations is the understanding that the bank may not employ this information for its own benefit in a manner possibly harmful to the client. If a court determines that such an understanding existed at the tine the information was commumicated-and the term "confidential" suggests that it did-then the court should honor them.

The case law, as noted earlier, affords ample basis for the protection of such expectations. The court nnight have chosen either a contractual or fiduciary analysis, both of which are grounded in the reasonable expectations of the parties. Unfortunately, the Washington

28. See text accompanying note 8 supra. 
Steel decision chose to ignore these cases and doctrines. Future courts should discount this portion of the decision as dicta and recognize that banks have a duty not to use confidential inforination in a manner that might harm their chents.

\section{Protecting Confidential Information: Procedural Mechanisms \\ a. The Per Se Rule}

The Washington Steel court's rejection of the per se rule, however, was justified. In a corporate banking relationship the chent reposes a certain measure of trust im its bank. Yet rarely is this trust of such scope as to merit a finding of a wide-ranging fiduciary relationship. ${ }^{29}$ Furthermore, the grounds for implying a broad contractual duty of loyalty are at best tenuous. Banks do not implicitly assume the duty of furthering or protecting the general corporate purposes of their chents merely by accepting confidential information from them. They may still, for exaunple, extend credit to such a client's competitors. In short, it is more consistent with the expectations of the parties to imply a limited duty, whether described as fiduciary or contractual, not to use the confidential information for purposes other than those for which it was entrusted.

It is conceded that a per se rule would provide the most effective protection agaimst misuse of confidential information. If banks were forbidden to place themselves in a position where there was even the appearance of impropriety, a substantial degree of protection would be afforded bank chents. However, as the Washington Steel court correctly poimted out, a per se rule would tend to burden the fiow of takeover financing. Corporations maintain an increasing number of banking relationships, ${ }^{30}$ and financing of tender offers is often in the form of syndicated loans; ${ }^{31}$ thus, there is a substantial possibility of a prior relationship between the target and one of the financing banks. In addition, the number of banks which have sufficient funds to participate in a takeover, particularly a substantial one, is limited. ${ }^{32}$ All of

29. The general principle is that the scope of a fiduciary's duties is determined by what the fiduciary has undertaken to do. See Scott, The Fiduciary Principle, 37 Callf. L. REv. 539, 540 (1949). Thus, for example, an agent's duty of loyalty to the principal is limited to matters connected with his agency. RESTATEMENT (SECOND) OF AGENCY $\$ 387$ (1957).

30. See Shapiro, supra note 1 , at 59 .

31. This was the case, for example, in American Medicorp, No. 77 C 3865 (N.D. Ill. Dec. 30, 1977) (unpublished opinion), where Continental Illinois and First National Bank in Boston were jointly financing the takeover.

32. For some statistics on the size of recent takeovers, see MERGERS \& ACQuisItIons, Summer 1979, at 66. Many of the transactions involved sums of money in the hundreds of millions of dollars. Of course, it might be argued that these huge transactions, where preclusion of one large commercial bank would have a noticeable impact on the availability of funding and therefore on the chance of consummation of the takeover, are precisely those which have the least social utility 
these factors increase the likelihood that under a per se rule acquiring coinpanies would encounter greater difficulty in obtaining takeover financing.

This argument is valid, of course, only if the desirability of corporate takeovers is assuined. Although economists differ on the matter, ${ }^{33}$ the congressional enactment of the Williams Act as a disclosure statute without attempting to discourage takeover bids is evidence of a legislative intent to sanction takeovers as a legitimate busmess activity. Indeed, the Senate Report recognized that "takeover bids should not be discouraged because they serve as a useful check on entrenched but inefficient management." ${ }^{34}$ For these reasons, the per se approach would constitute an undesirable judicial response to the confidentiahty problem.

\section{b. Internal Banking Procedures}

A more appropriate means of protecting bank chents' reasonable expectations of confidentiality would be to require the implementation of prophylactic imternal banking procedures known as the "Wall", or the so-called "Chinese Wall." The Wall is a device commercial banks $s^{35}$ and securities firms ${ }^{36}$ commonly employ to protect themselves against charges of conflict of interest and misuse of imside inforination. The principal purpose of the Wall is to cut off the flow of information between departments with conflictimg loyalties. For example, to prevent suspicion that inside information given to the loan department by a chent was used by the trust department in its mvestment decisions, a bank would restrict both access by trust department persoimel to fles from other departments and interdepartmental discussion of client matters.

because of the inherent risk of antitrust and other violations. It seems a sufficient answer, however, to point out that while Congress and various regulatory agencies have studied the problem of takeovers involving corporations the size of Exxon and Reliance Corp., takeovers of this scale are still legal and presumptively socially useful.

33. For a discussion on the economic benefits of takeovers, compare Kummer \& Hoffmeister, Valuation Consequences of Cash Tender Offers, 33 J. FInANCE 505 (1978), with Singh, Take-Overs, Economic Natural Selection, and the Theory of the Firm: Evidence from the Postwar United Kingdom Experience, 1975 EcoN. J. 497.

34. S. Rep. No. 550, 90th Cong., Ist Sess. 3 (1967). But cf. the statement issued by the Federal Reserve in a period of credit restraint: "Loans for purely financial activities sucl as acquisitions or the purcliase of a company's own shares, would normally not be appropriate uses of limited bank funds." 60 FED. RES. BULL. 679, 680 (1974). For a description of the Federal Reserve's similar policies in the present period of credit restraint, see Lancaster \& Leff, supra note 1.

35. See E. Herman, Conflicts of INTERest: Commerclal Bank Trust Departments (1975); Herzel \& Colling, The Chinese Wall and Confict of Interest in Banks, 34 Bus. LAw. 73 (1978).

36. See Lipton \& Mazur, The Chinese Wall Solution to the Confict Problems of Securities Firms, 50 N.Y.U.L. REv. 459 (1975). 
In the takeover situation, however, the Wall would of necessity be constructed within the bank loan department. To the extent practicable, confidential files of the target would be physically separated from other files. Bank officers working on the takeover loan would be denied access to the target's files and forbidden from discussing business with officers who had more than a passing familiarity with the target company's account. These latter officers would be disqualified froin working on the takeover loan. In extreme cases, where virtually all of the bank's senior officers were familiar with the target's files, the bank would be effectively precluded fron financing the takeover. In addition, since these procedures would necessarily be implemented immediately upon bank cognizance of pending takeover proceedings, bank officers would have to be educated in advance concerning their duties in such circumstances.

Requiring banks to implement the Wall would reduce the possibility of misuse of confidential information by bank officers working on the takeover loan. While it would still be possible, of course, for cases of intentional misuse to arise even with a Wall in place, inadvertent misuse would be rendered less likely by informing loan officers of their duties and by physically isolating sensitive files. To compel banks to implement such internal banking procedures, it is further urged that, absent such procedures, confidential information in the bank's possession be presumed to have influenced the bank in making its decision to finance the takeover. ${ }^{37}$

The banks themselves have found the Wall to be desirable. Most banks willing to finance a takeover of a client have decided to construct the Wall as a precautionary neasure. ${ }^{38}$ Their primary nuotivation is apparently litigation deterrence. If the existence of the Wall is considered by the courts to be prima facie evidence that confidential information has not been misused, spurious suits filed solely for the purpose of delaying takeovers can be quickly dismissed. Indeed, in Washington Steel, Chemical Bank had constructed a Wall, ${ }^{39}$ and, absent evidence of a breach of this Wall, the court found that plaintiff had not nuade a sufficient sliowing of misuse. ${ }^{40}$

37. Thus, in a situation such as American Medicorp, if the plaintiff could show that the bank was in possession of confidential information, the bank would be presumed to have violated its duty to its customer by using the information in its decision to finance the takeover.

38. See Shapiro, supra note 1. For a description of the conflicts-avoidance practices of a large Canadian bank in a takeover situation, see Malcolm, Canada's Banking Monolith, N.Y. Times, Apr. 24, 1979, at DI, col. 2.

39. 602 F.2d at 603.

40. Similarly, the court in Harnischfeger Corp. v. Paccar Inc., [1979] 2 Trade Cas. (CCH) \$ 62,786 (E.D. Wis. July 10, 1979), was convinced that there had been no misuse of confidential information by the fact that a Wall had been constructed. See note 16 supra. 
It is therefore reasonable to accept the Wall as the most appropriate compromise between the confidentiality interests of bank clients and the requirements of flexible and efficient banking sector operations. The proposed presumption concerning misuse would maximize a bank's incentive to impleinent the Wall while permitting bank financing of a takeover of a client if confidential information were protected. Under this regime, spurious suits could be quickly dismissed, while bank clients would still enjoy the possibility of redress if a breach of the Wall is shown. ${ }^{41}$

\section{B. Additional Considerations}

\section{Causation}

The recent cases suggest that a plaintiff challenging takeover financing on the basis of the confidentiality issue must show that the bank's consideration of the confidential information was the cause-infact of the takeover. ${ }^{42}$ It is reasoned that not all potential "misuses" of confidential information trigger takeover financing decisions. First, confidential information inust favorably reflect the future prospects of the target in order to induce bank approval of the takeover loan. Secondly, the "confidential" information must truly be unavailable to the general public. Public access to the information in question would clearly undermine any claim of confidentiality.

41. Few judicial decisions have discussed the Wall. The Second Circuit's opinion in Slade v. Shearson, Hamill \& Co., [1973-1974 Transfer Binder] FED. SEC. L. REP. (CCH) \94,329 (S.D.N.Y.), remanded 517 F.2d 398 (2d Cir. 1974), cast some doubt on the Wall's validity in the securities dealer setting. In Slade, plaintiffs claimed that Shearson, Hamill \& Co., a securities firm, had promoted purchases of TMl Corp. securities after its mvestınent banking arm had obtained adverse inside information about TMl. Shearson inoved for summary judgment on the theory, ainong others, that the firm's Wall policy precluded the possibihty that the inside information, even if received, had been communicated to the retail brokerage department. The district court rejected this argument, finding that there was still a inaterial issue of fact concerning this alleged lack of knowledge. (This argument was apparently raised by plaintiff but not discussed by the district court opinion. It was noted, however, in the appellate decision.) On appeal, the Court of Appeals for the Second Circuit, in an unusual disposition, remanded the case without decidimg the issue. The court refused to adopt a rule in the abstract since several important questions of fact, including whether the Wall had been in fact enforced, could be clarified by remand.

Since the district court opinion did not exphicitly refer to the Wall as a defense, it remains unclear whether the court disapproved of the Wall in principle or inerely found inadequate the particular Wall in question. Due to this uncertainty and the unusual appellate disposition of the case, Slade is doubtful authority and should be apphied with caution in the context of bank financing of takeovers.

42. The American Medicorp decision, see text accompanying notes 11-14 supra, apparently incorporated this causation requirement in its definition of "misuse." That court found that although a takeover loan officer had glanced through the target's files, the bank had used a "worst case" analysis in evaluating the loan by only considering the financial condition of the acquiring corporation. Under such an analysis, no "misuse" of the information was possible. It seems inore analytically sound, however, to define "misuse" to encoinpass any unauthorized use, and to treat causation separately. 
Even if the bank considered nonpublic information favorable to the target in its decisionmaking process, it is possible that the bank would nevertheless have decided to finance the takeover in the absence of such information. While logically such an arguinent may have inerit, it is submitted that to permit such a defense would raise coinplicated questions of fact concerning causation which would, in turn, likely create an insurmountable burden of proof for the plaintiff. A determination of whether or not the bank would have approved takeover financing even if it had not considered the confidential information would require an analysis of bank officers' individual exercise of discretion and of the bank's collective decisionmaking process. Since in inost cases the only direct evidence to this end would consist of testiinony froin these bank officers, it is unlikely that plaintiffs would be able to sustain this burden of proof.

To avoid this difficult proof problem, the plaintiff complaining of a breach of confidentiality should benefit froin one further presumption. If the bank officers responsible for the takeover loan can be shown to have been exposed to confidential information in breach of a self-imposed Wall, then the bank shonld be conclusively presumed to have relied on that information in its takeover financing decisionmaking process. Under this approach both the bank and its client would benefit froin additional protection. While plaintiffs would no longer bear the heavy burden of proving causation, banks would be capable of shielding themselves from breach of confidentiahty challenges by strictly adhering to self-imposed internal banking procedures. The judicial application of these presumptions would mutually enhance the prospects of fiduciary responsibility and takeover financing availability in the commercial banking context.

\section{Harm}

Related to the causation question is the issue of whether the target corporation or its shareholders suffer harm as a result of the bank's conduct. Although this issue was not presented under the Washington Steel facts, ${ }^{43}$ more difficult cases may arise in which the courts will be coinpelled to require a successful showing of both causation and harm before conferring liability upon a defendant bank.

Simce takeovers are not inherently harmful, a harm determination clearly cannot be grounded simply on the success of the takeover. Moreover, since the target's shareholders are free to accept or reject the

43. Since in Washington Steel the bank did not breach its own internal banking procedures, a discussion of the harm issue was unnecessary. 602 F.2d at 602-03. 
terms of the offer, it may be argued that neither they nor the corporation suffers any harm as a result of the offer.

But precisely in those circumstances where the bank has misused favorable nonpublic information, the bank's conduct may significantly harm its client. This is particularly true where the bank has financed a takeover which it knew from confidential information to be unfair to the target's shareliolders. If the bank was given nonpublic information whicl indicated that the target's prospects were much brighter than was generally known, the bank might well be inclined to finance a tender offer whose terms were unfair to the target's shareholders. Indeed, even where the originally conteinplated offer is fair, an influential bank may often be teinpted to press for a lower price. Simce in the takeover context its interest lies witlı the acquiring company, it is to the bank's advantage for the acquiring company to emerge financially sound after the takeover to ensure loan repayinent.

It might be suggested that the target management could simply release publicly the confldential information and thereby expose the unfair tender offer to its shareholders. Information is often confidential, however, because of the potential impact of its release upon the corporation. This would include information which would be helpful to the corporate competition, particularly sucln items as reports on future market strategies, new products, and future earnings. In such cases, the bank's breach would clearly occasion harm. Either the target shareholders would receive inadequate consideration for their shares or the competitive position of the corporation would be damaged as a consequence of this approach. ${ }^{44}$

Although the courts have failed to address the harm requirement in the takeover setting, the target plaintiff must nevertheless satisfy this requirement as a prerequisite to the judicial approval of an appropriate remedy. Indeed, the usual remedy sought by plaintiffs in takeover struggles is a preliminary injunction. It is generally held that a sub-

44. The standing of the corporation to complain of harm to its shareholders is also an issue here. The corporation and its shareholders are theoretically distinct legal entities. While a targct corporation may sue under the Williams Act to protect its shareholders from harm, this is pursuant to a federal private right of action derived froin statute. See Rondeau v. Mosinee Paper Corp., 422 U.S. 49 (1974). In contrast, at issue in this context is a common law duty nominally intended to protect the corporation rather than its shareholders.

Nevertheless, the legal distinction between the corporation and its shareholders is an unacceptable justification for the argument that, since the duty is owed to the corporation, the bank may cause the shareholders to be deprived of the full value of their shares so long as the corporation remains intact as a separate entity.

This is a situation where the corporation should as a inatter of policy be empowered to represent the interests of its stockholders. The stockholders are by assunption totally unaware of the confidential information which has been entrusted in the bank and obviously could not be expected to defend their own interests. 
stantial probability of irreparable injury is a requirement for the issuance of a preliminary injunction. ${ }^{45}$ Therefore, it is not sufficient for the target to inerely assert a breach of the duty of confidentiahty which is causally linked to the bank's decision to finance the tender offer. The courts should exphicitly require that future target plaintiffs demonstrate harm from the bank's breach of its own internal institutional procedures before a cause of action accrues on the confidentiality issue.

\section{CONCLUSION}

Commercial banks frequently deal with numerous chents whose interests necessarily are adverse. This operational mode proinotes efficiently functioning financial services. Inherent in the role of the bank, however, are certaim duties that it assumes toward its chents. These duties may be described as either fiduciary or contractual, and are based on the confidence that chents repose in their banks.

In Washington Steel Corp. v. TW Corp., the Court of Appeals for the Third Circuit, while reaching the correct disposition of the case, announced a rule in dicta that rejected the notion of confidentiahty im the bank-client relationship. The decision unfortunately neglected to address adequately the issue of the reasonable expectations of the parties, which should have provided the framework for the court's analysis. This Note has argued that the imposition of a duty on a bank not to misuse confidential information entrusted to it im a manner harmful to its clients merely lionors the original understanding of the parties.

This Note has also atteinpted to show that both the concerns of the banking sector and the expectations of bank clients can be accommodated by the use of internal banking procedures to protect confidential information from misuse. Moreover, it has proposed an analysis of the causation and harm issues which should be considered essential to a valid cause of action in this setting. Future judicial decisions would benefit from a more rigorous scrutimy of these identified substantive and procedural elements in cases similar to Washington Steel.

Howard Chao*

45. See generally 11 C. Wright \& A. Millegr, Federal Practice, ANd Procedure, $\$ 2948$ (1973). But see State v. Callaway, 497 F.2d 1235, 1241 (6th Cir. 1974).

* B.S. 1976, Purdue University; third-year student, Boalt Hall School of Law. 